\title{
Potential role of bromelain in clinical and therapeutic applications (Review)
}

\author{
VIDHYA RATHNAVELU ${ }^{1}$, NOORJAHAN BANU ALITHEEN ${ }^{2}$, SUBRAMANIAM SOHILA $^{3}$, \\ SAMIKANNU KANAGESAN ${ }^{4}$ and RAJENDRAN RAMESH ${ }^{5}$
}

\author{
${ }^{1}$ Department of Oral Pathology and Microbiology, Faculty of Dental Science, Sri Ramachandra University, \\ Chennai, Tamilnadu 600116, India; ${ }^{2}$ Department of Cell and Molecular Biology, Faculty of Biotechnology \\ and Biomolecular Sciences, University Putra Malaysia, Serdang, Selangor 43400, Malaysia; ${ }^{3}$ Department of Physics, \\ K. S. Rangasamy College of Technology, Tiruchengode, Tamilnadu 637215, India; ${ }^{4}$ Materials Synthesis \\ and Characterization Laboratory, Institute of Advanced Technology, University Putra Malaysia, Serdang, \\ Selangor 43400, Malaysia; ${ }^{5}$ Department of Physics, Periyar University, Salem, Tamilnadu 636011, India
}

Received April 21, 2016; Accepted July 7, 2016

DOI: $10.3892 /$ br.2016.720

\begin{abstract}
Pineapple has been used as part of traditional folk medicine since ancient times and it continues to be present in various herbal preparations. Bromelain is a complex mixture of protease extracted from the fruit or stem of the pineapple plant. Although the complete molecular mechanism of action of bromelain has not been completely identified, bromelain gained universal acceptability as a phytotherapeutic agent due to its history of safe use and lack of side effects. Bromelain is widely administered for its well-recognized properties, such as its anti-inflammatory, antithrombotic and fibrinolytic affects, anticancer activity and immunomodulatory effects, in addition to being a wound healing and circulatory improvement agent. The current review describes the promising clinical applications and therapeutic properties of bromelain.
\end{abstract}

\section{Contents}

1. Introduction

2. Anti-inflammatory activity of bromelain

3. Anticancer activity of bromelain

4. Antimicrobial activity

5. Clinical applications

6. Conclusion

Correspondence to: Dr Rajendran Ramesh, Department of Physics, Periyar University, Periyar Palkalai Nagar, Salem, Tamilnadu 636011, India

E-mail: rameshphys@gmail.com

Key words: bromelain, pineapple, anticancer, inflammation, anti-microbial, therapeutics

\section{Introduction}

During the sixteenth and seventeenth centuries, the pineapple plants were introduced to Asia Pacific and became the first commercial crop (1). Bromelain is a complex natural mixture of proteolytic enzymes derived from pineapple (Ananas cosmosus) and possesses notable therapeutic properties. There is continued interest in bromelain, which has been used for many years in folk medicine for various health problems. The potential therapeutic value of bromelain is due to its biochemical and pharmacological properties, and the main ingredient in crude bromelain is a proteolytic enzyme termed glycoprotein, which is in addition to insoluble materials, such as minerals, colored pigments, protease inhibitors, organic acids and organic solvents $(2,3)$. As yet, eight proteolytically active components have been isolated from bromelain (4). Proteinases are considered to be the most active fraction, which comprise $\sim 2 \%$ of the total proteins (5). Bromelain exerts its activity over a $\mathrm{pH}$ range of 4.5 to 9.5 (6). It is possible to isolate and purify bromelain using various methods. For commercial use, bromelain is prepared by centrifugation, ultrafilteration and lyophilization (7). The composition of bromelain varies based on the method of purification and the source; stem bromelain contains high quantities of protease content when compared with bromelain derived from the fruit (8). It was demonstrated that the majority of the physiological activity of bromelain may not be due to single proteolytic fraction, and it is likely that the beneficial effects of bromelain are due to multiple factors (9). Bromelain has not only been used to treat various health problems, it is also popular as a nutritional supplement to promote health. Bromelain is absorbed into the human intestines and remains biologically active with a half-life of $\sim 6-9 \mathrm{~h}$ (10). The highest concentration of bromelain was identified in the blood one hour after administration (11). Bromelain increases bioavailability and reduces the side effects that are associated with various antibiotics $(12,13)$. Furthermore, bromelain acts as an immunomodulator, is anti-metastatic, anti-edematous, anti-thrombotic and anti-inflammatory $(14,15)$. These findings 
indicate that bromelain may present as a promising candidate for the development of future anticancer therapeutic strategies. Notably, although numerous studies have been conducted regarding bromelain there are limited reviews that document the complete anticancer activity of bromelain. The focus of the current review was evidence for the anticancer effects of bromelain, which involve direct suppression of cancer cells, as well as evaluating the anti-inflammatory activity and immune system function modulation of bromelain. The future direction of research and the prospects for bromelain-based cancer therapy are presented.

\section{Anti-inflammatory activity of bromelain}

Inflammation is pivotal in the development of cancer during cellular transformation, proliferation, angiogenesis, invasion and metastasis. It has been demonstrated that suppression of chronic inflammation may reduce the cancer incidence and also inhibit cancer progression (16). Cyclooxigenase-2 (COX-2) is an important component of cancer-associated inflammation that is involved in the synthesis of prostaglandin E2 (PGE-2). PGE-2 is a pro-inflammatory lipid that also acts as an immunosuppressant, as well as a promoter of tumor progression (17). COX-2 converts arachidonic acid into PGE-2 and promotes tumor angiogenesis and cancer progression (18). It has been shown that bromelain downregulates COX-2 and PGE-2 expression levels in murine microglial cells and human monocytic leukemia cell lines (19). Bromelain activates the inflammatory mediators, including interleukin (IL)-1 $\beta$, IL-6, interferon (INF) $-\gamma$ and tumor necrosis factor (TNF)- $\alpha$ in mouse macrophage and human peripheral blood mononuclear cells (PBMC) (20-22). These results indicated that bromelain potentially activates the healthy immune system in association with the rapid response to cellular stress. Conversely, bromelain reduces IL-1 $\beta$, IL- 6 and TNF- $\alpha$ secretion when immune cells are already stimulated in the condition of inflammation-induced over production of cytokines $(23,24)$. Studies have shown that bromelain reduced the expression of INF- $\gamma$ and TNF- $\alpha$ in inflammatory bowel disease (25). A study demonstrated that bromelain diminished the cell damaging effect of advanced glycation end products by proteolytic degradation of receptor of advanced glycation end products (25) and controlled the inflammation (25). The cell surface marker, cluster of differentiation (CD)44 is expressed by cancer and immune cells directly involved in cancer growth and metastasis. Furthermore, CD44 regulates lymphocyte requirement at the site of inflammation $(26,27)$. Bromelain was shown to reduce the level of CD44 expression on the surface of mouse and human tumor cells, and regulate lymphocyte homing and migration to the sites of inflammation (28). Furthermore, bromelain modulates the expression of transforming growth factor (TGF)- $\beta$, one of the major regulators of inflammation in patients affected by osteomyelofibrosis and rheumatoid arthritis $(29,30)$. There are various studies that report the immunomodulatory effect of bromelain (31-34). Bromelain activates natural killer cells and augments the production of granulocyte-macrophage-colony stimulating factor, IL-2, IL-6 and decreases the activation of T-helper cells $(35,36)$. Thus, bromelain decreases the majority of inflammatory mediators and has demonstrated a significant role as an anti-inflammatory agent in various conditions (37).

\section{Anticancer activity of bromelain}

Effect on cell growth and survival pathways. In normal cells, cellular growth and proliferation are highly regulated, and imbalances of the cell cycle may lead to abandoned cellular growth and result in transformation to cancer cells. There are various pathways that are contained within cells to protect their DNA from damage resulting from toxicity and genomic instability (38). Checkpoint proteins are critical for monitoring the normal activity of the cell cycle. Tumor cells frequently lose checkpoint controls; therefore, regulation of cell cycle progression is employed one of the important approaches for cancer chemotherapy (39). It has been demonstrated that bromelain inhibits nuclear factor- $\kappa \mathrm{B}(\mathrm{NF}-\kappa \mathrm{B})$ translocation through $\mathrm{G}_{2} / \mathrm{M}$ arrest to apoptosis in human epidermoid carcinoma and melanoma cells (40). The process of apoptosis is fundamental in the developmental and homeostatic maintenance of complex biological systems. Failure of normal apoptotic mechanisms contributes to transformation of cells and provides a growth advantage to cancer cells (41). The apoptotic mechanism is characterized by cell shrinkage, chromatin condensation, DNA fragmentation and the activation of specific cysteine proteases, known as caspases (42). Generally, apoptosis is achieved by either mitochondrial pathways (intrinsic) or death receptor pathways (extrinsic). The mitochondrial pathway involves p53 functioning as a transcription factor to upregulate the expression of Bcl-2-like protein 4 (Bax), a pro-apoptotic protein. Bax antagonizes B-cell lymphoma 2 (Bcl-2), an anti-apoptotic protein that is present in the mitochondrial membrane (43). The protective effect of $\mathrm{Bcl}-2$ on the mitochondrial membrane is disrupted when the $\mathrm{Bax} / \mathrm{Bcl}-2$ ratio is increased. This facilitates the release of cytochrome $c$ into the cytosol and binds with apoptotic protease activating factor-1 to form an apoptosome complex. It initiates the caspase cascade via activation of caspase- 9 and results in cell death via enzymatic destruction of cytoplasmic proteins and DNA (44). Bromelain has been shown to selectively induce apoptosis in tumor cells by upregulation of p53 expression and initiation of the mitochondrial apoptotic pathway via increased Bax expression and cytochrome $c$ release (45). In addition, bromelain decreases the activity of cell survival regulators, such as Akt and extracellular signal-regulated kinases, thus promoting apoptotic cell death in tumors (46). In vitro bromelain treatment of established mouse tumor cell lines resulted in inhibition of cell growth and matrigel invasion capacities (47-50). It has been demonstrated that bromelain treatment significantly reduced the growth of gastric carcinoma Kato-III cell lines (51).

Effect on angiogenesis and metastasis. The metastatic spread of tumor cells from the original site is the cause of the high mortality rates associated with cancer. There are at least four interrelated biological events required for tumor metastasis: Angiogenesis, cell adhesion, cell invasion and cell proliferation (52). The interesting aspect of the anticancer activity of bromelain is its inhibitory effect on cancer metastasis. Bromelain potentially interferes with tumor metastasis progression at a variety of pivotal points (53). Bromelain inhibits cell 
surface adhesion proteins that are essential in cell adhesion, migration and inflammation (54). This inhibition is predominantly due to suppression of NF- $\mathrm{kB}$ activation. Furthermore, bromelain inhibits the invasiveness of human cancer cells by suppressing matrix metalloproteinase (MMP)-9 expression $(55,56)$ through inhibiting activator protein 1 (AP-1) and NF- $\mathrm{BB}$ signaling pathways $(42,57)$. A previous study demonstrated that bromelain initially suppresses the phosphorylation of NF- $\mathrm{KB}$ activation and then decreases the phosphorylation of c-Jun N-terminal kinases and subsequently AP-1 activation (58). In malignancies, there is a mutual association between platelets and tumor cells. Tumor cells initiate platelet activation, as well as the platelet-based production of multiple factors facilitating angiogenesis. Additionally, tumor cells, to varying degrees, possess the capacity to surround themselves with platelets, forming tumor-platelet aggregates that protect tumor cells from immune recognition (59). Oral administration of bromelain, as assessed by in vitro assays resulted in a reduction of platelet aggregation and activation (60). A previous study demonstrated that in vitro bromelain treatment of platelets from healthy volunteers significantly reduced platelet count (61). The ability of bromelain to inhibit platelet activation is associated with its proteolytic activity (17). Thus, the anti-platelet activity of bromelain interferes with platelet-mediated cancer growth and progression, and prevents the generation of tumor-platelet aggregates by un-coating cancer cells and exposing them to the immune system (62).

The stimulation of new blood vessel growth is an essential step for tumor growth and metastasis in order to provide for the metabolic needs of rapidly proliferating malignant cells. Angiogenesis is regulated by a variety of pro-angiogenic genes and signaling molecules, including vascular endothelial growth factor (VEGF), basic fibroblast growth factor (bFGF), epidermal growth factor (EGF), platelet-derived growth factors, hypoxia-inducible factors, angiopoetin-1 and 2, and MMPs (63). Bromelain has demonstrated an anti-angiogenic effect in various cancer cell lines $(47,64)$. Bromelain has been shown to regulate a variety of pro-angiogenic growth factors, enzymes and transcription factors including bFGF, VEGF, angiopoetin-1 and 2, COX-2, MMP-9, AP-1 and NF-kB $(41,65)$. Furthermore, bromelain has been shown to inhibit the angiogenic response to FGF-2 stimulation in mouse endothelial cells and decrease the expression of MMP-9, an enzyme involved in tissue remodeling that is important for the growth of new blood vessels (66). In addition, bromelain treatment decreased the levels of the angiogenic biomarkers, COX-2 and VEGF in hepatocellular carcinoma cells, and resulted in a reduction in tumor neo-capillary density when compared with untreated cells (67). In addition to its inhibitory effects on angiogenesis, bromelain has been demonstrated to affect a number of cellular adhesion molecules involved in the processes of tumor growth and metastasis (47).

\section{Antimicrobial activity}

Bromelain supplementation protects animals against diarrhea caused by bacterial enterotoxins from Escherichia coli and Vibrio cholerae (68). Bromelain acts as anti-adhesion agent by modifying the receptor attachment sites and influences the intestinal secretory signaling pathways $(69,70)$. In addition to its ability to counter certain effects of particular intestinal pathogens and its synergism with antibiotics, these two mechanisms are indicative of the benefits of bromelain against specific infections. In vitro evidence also suggests that bromelain exerts antihelminthic activity against the gastrointestinal nematodes, Trichuris muris and Heligmosomoides polygyrus $(71,72)$. Conversely, bromelain acts as an anti-fungal agent by stimulating phagocytosis and respiratory burst killing of Candida albicans when incubated with trypsin in vitro (73). Pityriasis lichenoides chronica is an infectious skin disease and bromelain reportedly caused complete resolution of this condition (74). Bromelain has been documented to increase blood and urine levels of certain antibiotics in humans (75-77). Combined bromelain and antibiotic therapy was shown to be more effective than antibiotics alone in pneumonia, bronchitis, cutaneous Staphylococcus infection, thrombophlebitis, cellulitis, pyelonephritis, and in perirectal and rectal abscesses (78), sinusitis (79) and urinary tract infections (80). A combination of bromelain, trypsin, and rutin has been administered as an adjuvant therapy in combination with antibiotics for children with sepsis (77). A combination of bromelain with enzymes derived from Aspergillus niger improved protein utilization in elderly nursing home patients (81). Another study demonstrated that bromelain, in combination with sodium alginate, sodium bicarbonate and essential oils, significantly improved dyspeptic symptoms (82). In addition, bromelain has been administered successfully as a digestive enzyme to treat intestinal disorders, pancreatectomy and exocrine pancreas insufficiency (83). Finally, the combination of ox bile, pancreatin, and bromelain is effective in lowering stool fat excretion in patients with pancreatic steatorrhea, resulting in symptomatic improvements in pain, flatulence and stool frequency (84).

\section{Clinical applications}

Currently bromelain is administered for numerous clinical applications due to its therapeutic effects in the treatment of inflammation and soft tissue injuries. A clinical study demonstrated that bromelain administered to boxers completely cleared all bruises on the face and haematomas of the orbits, lips, ears, chest and arms in four days (85). It has been demonstrated that orally administered bromelain is absorbed by the gut without losing its biological properties and significantly reduces the edema in traumatically-induced hind leg edema in rats (86). In vitro and in vivo analysis determined that administration of bromelain prevents aggregation of human blood platelets. Furthermore, in vitro and in vivo analysis indicated that bromelain administration prevents aggregation of human blood platelets and minimizes the severity of angina pectoris and transient ischemic attacks (35). Studies have also demonstrated the fibrinolytic activity (87), inhibition of thrombus formation (88) and platelet aggregation reduction resulting from bromelain treatment $(89,90)$. In addition, bromelain administration controlled the angina attacks and resulted in the disappearance of symptoms in hypertensive patients. Furthermore, angina attacks reappeared following discontinuation of bromelain after variable periods of time (up to 2 months) (87). Another study described that bromelain was effectively involved in the treatment of acute thrombophlebitis by decreasing the walking impairment in patients, 
and symptoms of inflammation, including skin temperature, tenderness, edema and pain (90). It has been shown that bromelain facilitated functional recovery of the heart by limiting myocardial injury in ischemia experiments (90). Bromelain also increased aortic flow, and reduced the infarct size and the degree of apoptosis $(90,91)$. A previous study demonstrated that bromelain treatment reduced apoptosis and endothelial cell damage in hepatic ischemia (92). In addition, there is an evidence that bromelain protected against ischemic injury in skeletal muscle (93). In vivo and in vitro studies have shown that bromelain dissolved arteriosclerotic plaque in rabbit aorta and it clearly explains the potent fibrinolytic activity of bromelain, which functions by breaking down cholesterol plaques $(94,95)$. In experimental animals, bromelain exerts an anti-hypertensive effect when administered for prolonged time periods. Furthermore, it increases vessel wall permeability to oxygen and nutrients while increasing blood fluidity (96). In patients suffering from inflammatory bowl diseases, bromelain administration reduces a variety of pro-inflammatory molecules, such as INF- $\gamma$ and colony stimulating factor (23). It has been reported that bromelain was successfully used in the treatment of ulcerative colitis and patients showed rapid improvement of symptoms (97). Furthermore, bromelain administration resulted in significant decrease in pain and stiffness in patients with knee osteoarthritis (98). In a murine model of acute asthma, bromelain decreased airway reactivity and sensitivity to irritants, decreased markers of lung inflammation (including infiltration by eosinophils and leukocytes) and moderated aspects of local airway immunity $(99,100)$. Numerous reports have documented the benefits of bromelain for sinusitis $(101,102)$. A previous study showed that administration of bromelain among children suffering from acute sinusitis shortened the duration of symptoms and accelerated recovery when compared with usual care regimens (103). Furthermore, sinusitis patients that received bromelain demonstrated complete resolution of breathing difficulties and inflammation of the nasal mucosa (104) and, in a rat model of rheumatoid arthritis, treatment with bromelain combined with cyclosporine reduced destructive arthritis and inflammation $(105,106)$. In addition, a clinical study demonstrated that bromelain was administered to patients with arthritic joint swelling and a significant to complete decrease in soft tissue swelling was observed (107).

\section{Conclusion}

Bromelain has been recognized as a safe and successful type of therapeutic agent, and is being used by individuals worldwide for a number of ailments, such as bronchitis, sinusitis, arthritis and inflammation. Various findings from traditional and clinical reports indicate that bromelain may be an effective anticancer therapeutic agent. From the in vitro and in vivo data that is currently available, bromelain demonstrates immunomodulatory and anti-neoplastic effects, in addition to anti-inflammatory and anti-microbial effects. The above-mentioned experimental evidence clearly demonstrates that bromelain exhibits efficacious chemopreventive capabilities entailing antitumor-initiating and -promoting effects via inhibition of tumor development, which is underlined by induction of $\mathrm{p} 53$, shifts in the $\mathrm{Bax} / \mathrm{Bcl}-2$ ratio, induction of caspases, decreases in Cox-2 expression and inhibition of the $\mathrm{NF}-\kappa \mathrm{B}$ pathway by regulating MAPK and Akt/PKB signaling pathways. Future studies in this area may lead to promising results for bromelain-based cancer therapy, anti-microbial agents and health supplements.

\section{References}

1. Morton J: Pineapple.In: Fruits of Warm Climates. Julia F. Morton, Miami, FL, pp18-28, 1987.

2. Scopes RK: Protein Purification: Principles and Practice. 2nd edition. Springer-Verlag, New York, NY, pp41-65, 1982.

3. Arnon R and Shapira E: Antibodies to papain. A selective fractionation according to inhibitory capacity. Biochemistry 6 : 3942-3950, 1967.

4. Ota S, Moore S and Stein WH: Preparation and chemical properties of purified stem and fruit bromelains. Biochemistry 3 : 180-185, 1964.

5. Murachi T, Yasui M and Yasuda Y: Purification and physical characterization of stem bromelain. Biochemistry 3: 48-55, 1964.

6. Hale LP, Greer PK, Trinh CT and James CL: Proteinase activity and stability of natural bromelain preparations. Int Immunopharmacol 5: 783-793, 2005.

7. Devakate RV, Patil VV, Waje SS and Thorat BN: Purification and drying of bromelain. Separ Purif Tech 64: 259-264, 2009.

8. Castell JV, Friedrich G, Kuhn CS and Poppe GE: Intestinal absorption of undegraded proteins in men: presence of bromelain in plasma after oral intake. Am J Physiol 273: G139-G146, 1997.

9. Maurer HR: Bromelain: Biochemistry, pharmacology and medical use. Cell Mol Life Sci 58: 1234-1245, 2001.

10. Mialovyts'ka OA: Effect of phlogenzym in long-term treatment of patients with multiple sclerosis. Lik Sprava: 109-113, 2003 (In Ukrainian).

11. White RR, Crawley FE, Vellini M and Rovati LA: Bioavailability of 125I bromelain after oral administration to rats. Biopharm Drug Dispos 9: 397-403, 1988.

12. Taussig SJ and Batkin S: Bromelain, the enzyme complex of pineapple (Ananas comosus) and its clinical application. An update. J Ethnopharmacol 22: 191-203, 1988.

13. Brien S, Lewith G, Walker A, Hicks SM and Middleton D: Bromelain as a treatment for osteoarthritis: a review of clinical studies. Evid Based Complement Alternat Med 1: 251-257, 2004.

14. Hale LP: Proteolytic activity and immunogenicity of oral bromelain within the gastrointestinal tract of mice. Int Immunopharmacol 4: 255-264, 2004.

15. Sarkar FH and Li Y: Cell signaling pathways altered by natural chemopreventive agents. Mutat Res 555: 53-64, 2004.

16. Huang JR, Wu CC, Hou RC and Jeng KC: Bromelain inhibits lipopolysaccharide-induced cytokine production in human THP-1 monocytes via the removal of CD14. Immunol Invest 37: 263-277, 2008.

17. Bhui K, Prasad S, George J and Shukla Y: Bromelain inhibits COX-2 expression by blocking the activation of MAPK regulated NF-kappa B against skin tumor-initiation triggering mitochondrial death pathway. Cancer Lett 282: 167-176, 2009.

18. Gaspani L, Limiroli E, Ferrario P and Bianchi M: In vivo and in vitro effects of bromelain on PGE(2) and SP concentrations in the inflammatory exudate in rats. Pharmacology 65: 83-86, 2002.

19. Desser L, Rehberger A and Paukovits W: Proteolytic enzymes and amylase induce cytokine production in human peripheral blood mononuclear cells in vitro. Cancer Biother 9: 253-263, 1994.

20. Engwerda CR, Andrew D, Murphy M and Mynott TL: Bromelain activates murine macrophages and natural killer cells in vitro. Cell Immunol 210: 5-10, 2001.

21. Engwerda CR, Andrew D, Ladhams A and Mynott TL: Bromelain modulates $\mathrm{T}$ cell and $\mathrm{B}$ cell immune responses in vitro and in vivo. Cell Immunol 210: 66-75, 2001.

22. Barth H, Guseo A and Klein R: In vitro study on the immunological effect of bromelain and trypsin on mononuclear cells from humans. Eur J Med Res 10: 325-331, 2005.

23. Onken JE, Greer PK, Calingaert B and Hale LP: Bromelain treatment decreases secretion of pro-inflammatory cytokines and chemokines by colon biopsies in vitro. Clin Immunol 126: 345-352, 2008.

24. Hale LP, Greer PK, Trinh CT and Gottfried MR: Treatment with oral bromelain decreases colonic inflammation in the IL-10-deficient murine model of inflammatory bowel disease. Clin Immunol 116: 135-142, 2005. 
25. Stopper H, Schinzel R, Sebekova K and Heidland A: Genotoxicity of advanced glycation end products in mammalian cells. Cancer Lett 190: 151-156, 2003.

26. Makrydimas G, Zagorianakou N, Zagorianakou P and Agnantis NJ: CD44 family and gynaecological cancer. In Vivo 17: 633-640, 2003.

27. Subramaniam V, Gardner H and Jothy S: Soluble CD44 secretion contributes to the acquisition of aggressive tumor phenotype in human colon cancer cells. Exp Mol Pathol 83: 341-346, 2007.

28. Massagué J: TGFbeta in Cancer. Cell 134: 215-230, 2008.

29. Bierie B and Moses HL: Tumour microenvironment: TGFbeta: the molecular Jekyll and Hyde of cancer. Nat Rev Cancer 6: 506-520, 2006.

30. Leipner J, Iten F and Saller R: Therapy with proteolytic enzymes in rheumatic disorders. BioDrugs 15: 779-789, 2001

31. Vellini M, Desideri D, Milanese A, Omini C, Daffonchio L, Hernandez A and Brunelli G: Possible involvement of eicosanoids in the pharmacological action of bromelain. Arzneimittelforschung 36: 110-112, 1986.

32. Inoue K, Motonaga A, Dainaka J, Nishimura T, Hashii H, Yamate K, Ueda F and Kimura K: Effect of etodolac on prostaglandin E2 biosynthesis, active oxygen generation and bradykinin formation. Prostaglandins Leukot Essent Fatty Acids 51: 457-462, 1994.

33. Oh-ishi S, Uchida Y, Ueno A and Katori M: Bromelian, a thiolprotease from pineapple stem, depletes high molecular weight kininogen by activation of Hageman factor (Factor XIII). Thromb Res 14: 665-672, 1979.

34. Seligman B: Bromelain: An anti-inflammatory agent. Angiology 13: 508-510, 1962

35. Giacca S: Clinical experiences on the action of bromelin in peripheral venous diseases and in chronic bronchitic states. Minerva Med 56: 104, 1965 (In Italian).

36. Moss JN, Frazier CV and Martin GJ: Bromelains. The pharmacology of the enzymes. Arch Int Pharmacodyn Ther 145: $166-189,1963$

37. De-Giuli M and Pirotta F: Bromelain, interaction with some protease inhibitor and rabbit specific antiserum. Drugs Exp Clin Res 4: 21-23, 1978.

38. Chobotova K, Vernallis AB and Majid FA: Bromelain's activity and potential as an anti-cancer agent: current evidence and perspectives. Cancer Lett 290: 148-156, 2010.

39. Beuth J and Braun JM: Modulation of murine tumor growth and colonization by bromelaine, an extract of the pineapple plan (Ananas comosum L.). In Vivo 19: 483-485, 2005.

40. Báez R, Lopes MT, Salas CE and Hernández M: In vivo antitumoral activity of stem pineapple (Ananas comosus) bromelain Planta Med 73: 1377-1383, 2007.

41. Zavadova E, Desser L and Mohr T: Stimulation of reactive oxygen species production and cytotoxicity in human neutrophils in vitro and after oral administration of a polyenzyme preparation. Cancer Biother 10: 147-152, 1995.

42. Eckert K, Grabowska E, Stange R, Schneider U, Eschmann K and Maurer HR: Effects of oral bromelain administration on the impaired immunocytotoxicity of mononuclear cells from mammary tumor patients. Oncol Rep 6: 1191-1199, 1999.

43. Snowden HM, Renfrew MJ and Woolridge MW: Treatments for breast engorgement during lactation. Cochrane Database Syst Rev 2: CD000046, 2001.

44. Guimarães-Ferreira CA, Rodrigues EG, Mortara RA, Cabral H, Serrano FA, Ribeiro-dos-Santos R and Travassos LR: Antitumor effects in vitro and in vivo and mechanisms of protection against melanoma B16F10-Nex2 cells by fastuosain, a cysteine proteinase from Bromelia fastuosa. Neoplasia 9: 723-733, 2007.

45. Tysnes BB, Maurer HR, Porwol T, Probst B, Bjerkvig R and Hoover F: Bromelain reversibly inhibits invasive properties of glioma cells. Neoplasia 3: 469-479, 2001.

46. Mantovani A, Allavena P, Sica A and Balkwill F: Cancer-related inflammation. Nature 454: 436-444, 2008.

47. Juhasz B, Thirunavukkarasu M, Pant R, Zhan L, Penumathsa SV, Secor ER Jr, Srivastava S, Raychaudhuri U, Menon VP, Otani $\mathrm{H}$, et al: Bromelain induces cardioprotection against ischemia-reperfusion injury through $\mathrm{Akt} / \mathrm{FOXO}$ pathway in rat myocardium. Am J Physiol Heart Circ Physiol 294: H1365-H1370, 2008.

48. Ferris RL and Grandis JR: NF-kappaB gene signatures and p53 mutations in head and neck squamous cell carcinoma. Clin Cancer Res 13: 5663-5664, 2007.

49. Chen F, Beezhold K and Castranova V: Tumor promoting or tumor suppressing of NF-kappa B, a matter of cell context dependency. Int Rev Immunol 27: 183-204, 2008.
50. Hou RC, Chen YS, Huang JR and Jeng KC: Cross-linked bromelain inhibits lipopolysaccharide-induced cytokine production involving cellular signaling suppression in rats. J Agric Food Chem 54: 2193-2198, 2006.

51. Taussig SJ, Szekerczes J and Batkin S: Inhibition of tumour growth in vitro by bromelain, an extract of the pineapple plant (Ananas comosus). Planta Med 51: 538-539, 1985.

52. Kleef R, Delohery TM and Bovbjerg DH: Selective modulation of cell adhesion molecules on lymphocytes by bromelain protease 5. Pathobiology 64: 339-346, 1996.

53. Gerard G: Anti-cancer therapy with bromelain. Agress 3: 261-274, 1972.

54. Nieper HA: A program for the treatment of cancer. Krebs 6: 124-127, 1974

55. Philchenkov A: Caspases: potential targets for regulating cell death. J Cell Mol Med 8: 432-444, 2004.

56. Li Q, Withoff S and Verma IM: Inflammation-associated cancer: NF-kappaB is the lynchpin. Trends Immunol 26: 318-325, 2005.

57. Oltersdorf T, Elmore SW, Shoemaker AR, Armstrong RC, Augeri DJ, Belli BA, Bruncko M, Deckwerth TL, Dinges J, Hajduk PJ, et al: An inhibitor of Bcl-2 family proteins induces regression of solid tumours. Nature 435: 677-681, 2005.

58. Netti C, Bandi GL and Pecile A: Anti-inflammatory action of proteolytic enzymes of animal vegetable or bacterial origin administered orally compared with that of known anti-phlogistic compounds. Farmaco Prat 8: 453-466, 1972.

59. Smyth RD, Brennan R and Martin GJ: Systemic biochemical changes following the oral administration of a proteolytic enzyme, bromelain. Arch Int Pharmacodyn Ther 136: 230-236, 1962.

60. Garbin F, Harrach T, Eckert K and Maurer HR: Bromelain proteinase-f9 augments human lymphocyte-mediated growth-inhibition of various tumor cells in vitro. Int J Oncol 5: 197-203, 1994.

61. Gläser D and Hilberg T: The influence of bromelain on platelet count and platelet activity in vitro. Platelets 17: 37-41, 2006.

62. Kalra N, Bhui K, Roy P, Srivastava S, George J, Prasad S and Shukla Y: Regulation of p53, nuclear factor kappaB and cyclooxygenase- 2 expression by bromelain through targeting mitogen-activated protein kinase pathway in mouse skin. Toxicol Appl Pharmacol 226: 30-37, 2008.

63. Kim JK, Kim Y, Na KM, Surh YJ and Kim TY: [6]-Gingerol prevents UVB-induced ROS production and COX-2 expression in vitro and in vivo. Free Radic Res 41: 603-614, 2007.

64. Karlsen M, Hovden AO, Vogelsang P, Tysnes BB and Appel S: Bromelain treatment leads to maturation of monocyte-derived dendritic cells but cannot replace PGE2 in a cocktail of IL-1 $\beta$, IL-6, TNF- $\alpha$ and PGE2. Scand J Immunol 74: 135-143, 2011

65. Wu SY, Hu W, Zhang B, Liu S, Wang JM and Wang AM: Bromelain ameliorates the wound microenvironment and improves the healing of firearm wounds. J Surg Res 176: 503-509, 2012

66. Wallace JM: Nutritional and botanical modulation of the inflammatory cascade - eicosanoids, cyclooxygenases, and lipoxygenases - as an adjunct in cancer therapy. Integr Cancer Ther 1: 7-37, 2002.

67. Manosroi A, Chankhampan C, Manosroi W and Manosroi J: Toxicity reduction and MMP-2 stimulation of papain and bromelain loaded in elastic niosomes. J Biomed Nanotechnol 8: 720-729, 2012.

68. Mynott TL, Guandalini S, Raimondi F and Fasano A: Bromelain prevents secretion caused by Vibrio cholerae and Escherichia coli enterotoxins in rabbit ileum in vitro. Gastroenterology 113: 175-184, 1997.

69. Chandler DS and Mynott TL: Bromelain protects piglets from diarrhoea caused by oral challenge with K88 positive enterotoxigenic Escherichia coli. Gut 43: 196-202, 1998.

70. Mynott TL, Luke RK and Chandler DS: Oral administration of protease inhibits enterotoxigenic Escherichia coli receptor activity in piglet small intestine. Gut 38: 28-32, 1996.

71. Stepek G, Lowe AE, Buttle DJ, Duce IR and Behnke JM: In vitro and in vivo anthelmintic efficacy of plant cysteine proteinases against the rodent gastrointestinal nematode, Trichuris muris. Parasitology 132: 681-689, 2006.

72. Stepek G, Buttle DJ, Duce IR, Lowe A and Behnke JM: Assessment of the anthelmintic effect of natural plant cysteine proteinases against the gastrointestinal nematode, Heligmosomoides polygyrus, in vitro. Parasitology 130: 203-211, 2005. 
73. Brakebusch M, Wintergerst U, Petropoulou T, Notheis G, Husfeld L, Belohradsky BH and Adam D: Bromelain is an accelerator of phagocytosis, respiratory burst and Killing of Candida albicans by human granulocytes and monocytes. Eur J Med Res 6: 193-200, 2001.

74. Massimiliano R, Pietro R, Paolo S, Sara P and Michele F: Role of bromelain in the treatment of patients with pityriasis lichenoides chronica. J Dermatolog Treat 18: 219-222, 2007.

75. Tinozzi S and Venegoni A: Effect of bromelain on serum and tissue levels of amoxicillin. Drugs Exp Clin Res 4: 39-44, 1978.

76. Luerti M and Vignali ML: Influence of bromelain on penetration of antibiotics in uterus, salpinx and ovary. Drugs Exp Clin Res 4: 45-48, 1978.

77. Shahid SK, Turakhia NH, Kundra M, Shanbag P, Daftary GV and Schiess W: Efficacy and safety of phlogenzym - a protease formulation, in sepsis in children. J Assoc Physicians India 50: 527-531, 2002.

78. Neubauer RA: A plant protease for potentiation of and possible replacement of antibiotics. Exp Med Surg 19: 143-160, 1961.

79. Ryan RE: A double-blind clinical evaluation of bromelains in the treatment of acute sinusitis. Headache 7: 13-17, 1967.

80. Mori S, Ojima Y, Hirose T, Sasaki T and Hashimoto Y: The clinical effect of proteolytic enzyme containing bromelain and trypsin on urinary tract infection evaluated by double blind method. Acta Obstet Gynaecol Jpn 19: 147-153, 1972.

81. Glade MJ, Kendra D and Kaminski MV Jr: Improvement in protein utilization in nursing-home patients on tube feeding supplemented with an enzyme product derived from Aspergillus niger and bromelain. Nutrition 17: 348-350, 2001.

82. Knill-Jones RP, Pearce H, Batten J and Williams R: Comparative trial of Nutrizym in chronic pancreatic insufficiency. BMJ 4 21-24, 1970.

83. Balakrishnan V, Hareendran A and Nair CS: Double-blind cross-over trial of an enzyme preparation in pancreatic steatorrhoea. J Assoc Physicians India 29: 207-209, 1981

84. Pellicano R, Strona S, Simondi D, Reggiani S, Pallavicino F, Sguazzini C, Bonagura AG, Rizzetto $M$ and Astegiano $M$ Benefit of dietary integrators for treating functional dyspepsia: a prospective pilot study. Minerva Gastroenterol Dietol 55: 227-235, 2009

85. Blonstein JL: Control of swelling in boxing injuries. Practitioner 185: 78, 1960.

86. Uhlig G and Seifert J: The effect of proteolytic enzymes (traumanase) on posttraumatic edema. Fortschr Med 99. 554-556, 1981 (In German).

87. Nieper HA: Effect of bromelain on coronary heart disease and angina pectoris. Acta Med Empirica 5: 274-278, 1978.

88. Nieper HA: Decrease of the incidence of coronary heart infarct by $\mathrm{Mg}$ - and K-orotate and bromelain. Acta Med Empirica 12: 614-618, 1977.

89. Seligman B: Oral bromelains as adjuncts in the treatment of acute thrombophlebitis. Angiology 20: 22-26, 1969.
90. Gutfreund AE, Taussig SJ and Morris AK: Effect of oral bromelain on blood pressure and heart rate of hypertensive patients. Hawaii Med J 37: 143-146, 1978.

91. Gailhofer G, Wilders-Truschnig M, Smolle J and Ludvan M Asthma caused by bromelain: an occupational allergy. Clin Allergy 18: 445-450, 1988.

92. Bahde R, Palmes D, Minin E, Stratmann U, Diller R, Haier J and Spiegel HU: Bromelain ameliorates hepatic microcirculation after warm ischemia. J Surg Res 139: 88-96, 2007.

93. Bloomer RJ: The role of nutritional supplements in the prevention and treatment of resistance exercise-induced skeletal muscle injury. Sports Med 37: 519-532, 2007.

94. Felton GE: Fibrinolytic and antithrombotic action of bromelain may eliminate thrombosis in heart patients. Med Hypotheses 6 : $1123-1133,1980$.

95. Lotz-Winter H: On the pharmacology of bromelain: an update with special regard to animal studies on dose-dependent effects. Planta Med 56: 249-253, 1990.

96. Shibayama Y: An experimental study into the cause of acute haemorrhagic gastritis in cirrhosis. J Pathol 149: 307-313, 1986

97. Kane S and Goldberg MJ: Use of bromelain for mild ulcerative colitis. Ann Intern Med 132: 680, 2000.

98. Walker AF, Bundy R, Hicks SM and Middleton RW: Bromelain reduces mild acute knee pain and improves well-being in a dose-dependent fashion in an open study of otherwise healthy adults. Phytomedicine 9: 681-686, 2002.

99. Secor ER, Carson WF, Singh A, Pensa M, Guernsey LA, Schramm CM and Thrall RS: Oral bromelain attenuates inflammation in an ovalbumin-induced murine model of asthma. Evid Based Complement Alternat Med 5: 61-69, 2008.

100. Secor ER Jr, Carson WF IV, Cloutier MM, Guernsey LA, Schramm CM, Wu CA and Thrall RS: Bromelain exerts anti-inflammatory effects in an ovalbumin-induced murine model of allergic airway disease. Cell Immunol 237: 68-75, 2005

101. Seltzer AP: Adjunctive use of bromelains in sinusitis: a controlled study. Eye Ear Nose Throat Mon 46: 1281-1288, 1967.

102. Braun JM, Schneider B and Beuth HJ: Therapeutic use, efficiency and safety of the proteolytic pineapple enzyme Bromelain-POS in children with acute sinusitis in Germany. In Vivo 19: 417-421, 2005

103.Zatuchni GI and Colombi DJ: Bromelains therapy for the prevention of episiotomy pain. Obstet Gynecol 29: 275-278, 1967.

104. Ahle NW and Hamlet MP: Enzymatic frostbite eschar debridement by bromelain. Ann Emerg Med 16: 1063-1065, 1987

105. Rovenská E, Svík K, Stancíková M and Rovenský J: Enzyme and combination therapy with cyclosporin $\mathrm{A}$ in the rat developing adjuvant arthritis. Int J Tissue React 21: 105-111, 1999.

106. Cohen A and Goldman J: Bromelain's therapy in rheumatoid arthritis. Pa Med J 67: 27-30, 1964.

107. Grover AK and Samson SE: Benefits of antioxidant supplements for knee osteoarthritis: rationale and reality. Nutr J 15: 1, 2016. 